\title{
SHORELINE CHANGE AND COASTAL VULNERABILITY CHARACTERIZATION WITH LANDSAT IMAGERY: A CASE STUDY IN THE OUTER HEBRIDES, SCOTLAND
}

\section{Authors:}

\author{
CRISTINA GÓMEZ ${ }^{1, *}$, MICHAEL A. WULDER ${ }^{2}$, ALASTAIR G. DAWSON ${ }^{1}$, WILLIAM \\ RITCHIE $^{1}$, DAVID R. GREEN ${ }^{1}$
}

\begin{abstract}
Affiliations:
${ }^{1}$ Aberdeen Institute for Coastal Science and Management (AICSM), Department of Geography and Environment, School of Geoscience, University of Aberdeen, Aberdeen AB24 3UE, Scotland, UK.

${ }^{2}$ Canadian Forest Service (Pacific Forestry Centre), Natural Resources Canada, 506 West Burnside Road, Victoria, British Columbia, V8Z 1M5, Canada

*Corresponding author: Cristina Gómez

Phone: +44 1466 792006; Email: c.gomez@abdn.ac.uk
\end{abstract}

\section{Pre-print of published version.}

\section{Reference:}

Gómez, C., Wulder, M.A., Dawson, A.G, Ritchie, W., Green, D.R. 2014. Shoreline change and coastal vulnerability characterization with Landsat imagery: a case study in the Outer Hebrides, Scotland. Scottish Geographical Journal,

DOI. http://dx.doi.org/10.1080/14702541.2014.923579

\section{Disclaimer:}

The PDF document is a copy of the final version of this manuscript that was subsequently accepted by the journal for publication. The paper has been through peer review, but has not been subject to any additional copy-editing or journal specific formatting (so will look different from the final version of record, which may be accessed following the DOI above depending on your access situation) 


\begin{abstract}
Observation of cause-effect patterns of change in coastal environments provides insights into vulnerable areas and supports prediction and adaptation to flooding and erosion. Historic and periodic (6-8 year intervals) imagery from the Landsat archive is used to investigate transformations in the Atlantic coast of two Scottish islands over the period 1989-2011. Supervised classification of spectrally normalized images followed by change detection and spatial analysis reveals the patterns of change and the location of the most dynamic coastal areas. Quantitative measures of recent shifts and movement rates of relevant coastal lines, such as the lower limit of land-based vegetation are assessed with the Digital Shoreline Analysis System (DSAS). While very low rates are indicated for horizontal changes in the position of the lower limit of land-based vegetation $\left(0.3 \mathrm{~m} \mathrm{y}^{-1}\right)$, specific areas have been subject to high rates of coastal progradation as well as erosion (e.g., $2.5 \mathrm{~m} \mathrm{y}^{-1}$ at Stilligarry). Information derived from satellite data supports the characterization of geomorphologically dynamic coasts at regional scales. With a rich and open access archive of imagery, a commitment to continuity, and compatibility with the Earth observation missions of other space programs, the Landsat mission offers useful and otherwise unavailable data for monitoring of coastal areas.
\end{abstract}

Key words: shoreline change, vulnerability, Landsat, spatial analysis, Digital Shoreline Analysis System, Scottish Outer Hebrides 


\section{Introduction}

Coastal environments change in a continuous fashion under the influence of both natural and anthropogenic factors, and at temporal scales ranging from hours to decades and longer (Carter, 1989). Agents inducing short term change include storm events (Chatenoux and Peduzzi, 2007) and engineering developments (Burak et al., 2004), while among long term factors sea level variation and sediment supply are notable (Devoy 1987; Thom and Cowell, 2005). The assessment of past coastal change, including trends of shore erosion and accretion is fundamental to a broad range of investigations undertaken by coastal scientists, engineers, and managers, in particular those that focus on interpretation of coastal hazard, sediment budget analysis, and coastal morphodynamics (Maiti and Bhattacharya, 2011). Thus, historic coast change information is of considerable importance in providing insights on status and temporal patterns of change, allowing development of a range of projections on coastal functioning.

The Hebridean coast of Scotland has been subject to a progressive but regionally variable rise in relative sea level since the mid-Holocene, as a consequence of postglacial isostatic adjustment and glacio-eustatic sea level rise (SLR), but local average rates of SLR seem to have increased since 1990 (Cazenave and Nerem, 2004; Church and White, 2006) with related impacts on coastal areas. The effects of winter storms on the coastline are a response to changes in the North Atlantic Oscillation that, in turn, are responsive to changes in the position of the North Atlantic storm track (Lozano et al., 2004; Weisse et al., 2012). In general, storms that persist longer than the diurnal tidal cycle are associated with notable coastal change. While SLR, monthly tidal cycles, and storm activity are the major natural causes of coastal change, sediment supply is crucial for processes of accretion and remodelling (Rennie, 2006).

The Atlantic coast of the Scottish Outer Hebrides is low lying, with substantial areas beneath the highest astronomical tide. Separated from the coast by a system of low dunes (Ritchie, 1972; Dawson et al., 2012a) these low lying lands are vulnerable to relative SLR. Marine flooding with brackish water can be expected to alter or entail damage to specific habitats (Angus and Hansom, 2004) which could lead to a reduction in agricultural land. Long-term rates of historical shoreline recession have been highly variable over the last century, with limited coastal retreat over the last two decades (Dawson et al., 2007a, 2012b). Interpretation of recent and archival data demonstrated that the area is 
continuously evolving and has lately been subject to significant episodes of change. Despite intensive research, a gap of suitable data to explain the causality of changes still exists. Addressing this information gap will enable insights about the causes of change, such as episodic extreme events or continuous forcing (e.g. SLR, long-term storminess), and will help development of future coastal conditions scenarios. In this research, our goal is to investigate opportunities of medium spatial resolution (MSR; pixels sized 10 to $100 \mathrm{~m}$ ) imagery acquired from Earth observing satellites to assist in the assessment of coastal change and risks at an adequate spatio-temporal scale, to support management decisions for adaptation to change. Imagery from the Landsat program is used as a standard, consistent, and accessible source of data, highly compatible with other programs. The techniques applied in the Outer Hebrides of Scotland are considered generic and suitable for application to other coastal areas with similar needs. Specific objectives supporting the main aim include:

- To identify with spatially explicit detail shore areas that have experienced significant change between 1989 and 2011, by capitalizing on the distinctive spectral properties of land cover materials, systematic categorization of landscape units, and detection of change over time to interpret morphological changes.

- To statistically assess recent shifts in coastal lines and rates of movement for evaluation of coastal dynamics and mid-term trends of change.

- To explore the potential of patterns of relatively recent historical changes to infer current states of vulnerability to erosion and coastal flooding. 


\section{Background}

The coastline is a naturally transient boundary between land and sea water, commonly identified by coastal indicators (Boak and Turner, 2005). As it is subject to persistent and diffuse change, any measure or depiction of the coastline represents a momentary condition of little stability. Thus, in addition to inherent technical limitations, any effort to measure and map coastal change is subject to natural uncertainties related to the elusiveness of the concept. Traditional monitoring of coastal change through periodically surveyed cross-sectional profiles and expert interpretation has long been supported with aerial photography and other geospatial technologies. More recently, Global Navigation Satellite Systems (GNSS) (Morton et al., 1993; Desprats et al., 2010; Taylor and O’Donoghue, 2009), airborne laser scanner (ALS) (Stockdon et al., 2002; Zhang et al., 2005; Sallenger et al., 2003) and Synthetic Aperture Radar (SAR) (Mason and Davenport, 1996; Wang and Allen, 2008) have been demonstrated to provide precise measures that enable accurate calculations of coastal change. Although effective, these techniques are often restricted by high costs and limitations to data acquisition and processing, both temporally and spatially, regarding the characterization of large areas. Alternatively, satellite imagery acquired in a synoptic and repeated manner with consistent spectral and spatial resolutions can provide spatially exhaustive data captured over accessible and nonaccessible locations.

\section{Detection of Shorelines and Monitoring of Coastal Change with Satellite Optical Sensors}

Earth Observation at a medium spatial resolution (pixels sized 10 to $100 \mathrm{~m}$ ) from polar orbiting satellites has been undertaken for more than four decades (Wulder et al., 2011) and will continue in the future (Irons et al., 2012; Drusch et al., 2012). Satellite data provide consistent measurements at a variety of scales suitable for assessment of change in coastal ecosystems (Klemas, 2011) and are buttressed by well established and emergent techniques of processing and analysis (Wulder et al., 2008). Optical sensors are well suited for detection of coastal change (Table 1) and combined with GIS tools facilitate monitoring of landscape transformation. 
Table 1. Studies using Landsat imagery for identification of the coastline, waterline movements, and patterns of sediment erosion and accretion

\begin{tabular}{|c|c|c|c|}
\hline \multirow{2}{*}{ Method } & \multirow{2}{*}{ Technique } & Study & Goal \\
\hline & & Location & Date-Period \\
\hline \multirow{6}{*}{ Digitization } & \multirow{2}{*}{$\begin{array}{l}\text { Visualization of Water } \\
\text { indices }\end{array}$} & El-Asmar and Hercher, 2010 & $\begin{array}{l}\text { Change in coastal position } \\
\text { Assessment of erosion/accretion }\end{array}$ \\
\hline & & Nile Delta (Egypt) & $(1973-2007)$ \\
\hline & \multirow{2}{*}{$\begin{array}{l}\text { Visualization of (Green, red, } \\
\text { NIR) and NDVI }\end{array}$} & Rahman et al. 2011 & Assessment of erosion/accretion \\
\hline & & \begin{tabular}{|l|} 
Sundarban (Bangladesh) \\
\end{tabular} & $(1973-2010)$ \\
\hline & \multirow{2}{*}{ Visualization of NIR } & Maiti and Bhattacharya, 2009 & Assessment of shoreline change \\
\hline & & Bay of Bengal (India) & $(1973-2003)$ \\
\hline \multirow{14}{*}{ Classification } & \multirow[b]{2}{*}{ Soft classification } & Muslim et al. 2007(*) & Shoreline delineation \\
\hline & & $\begin{array}{l}\text { Seberang Takir, Terengganu } \\
\text { (Malaysia) }\end{array}$ & $(2000)$ \\
\hline & \multirow{2}{*}{$\begin{array}{l}\text { ISODATA classification } \\
\text { SWIR }\end{array}$} & Yu et al. 2011 & Shoreline change identification \\
\hline & & Central Florida (USA) & $(1987-2008)$ \\
\hline & \multirow{2}{*}{$\begin{array}{l}\text { Binary images by thresh- } \\
\text { holding MSS4 and TM7 }\end{array}$} & Dewidar and Frihy, 2010 & \multirow{2}{*}{$\begin{array}{l}\text { Assessment of erosion/accretion } \\
(1972-2007)\end{array}$} \\
\hline & & Nile Delta (Egypt) & \\
\hline & \multirow{2}{*}{$\begin{array}{l}\text { Depth invariant bottom } \\
\text { indices }\end{array}$} & Vanderstraete et al. 2006 & $\begin{array}{l}\text { Land use change } \\
\text { Assessment of erosion/accretion }\end{array}$ \\
\hline & & Hurghada (Egypt) & $(1987-2000)$ \\
\hline & \multirow{2}{*}{ Histogram density slicing } & Ryu et al. 2002 & Assessment of waterline change \\
\hline & & Gomso Bay (Korea) & $(1986-2001)$ \\
\hline & \multirow{2}{*}{$\begin{array}{l}\text { Supervised classification (3 } \\
\text { classes) }\end{array}$} & Maiti and Bhattacharya, 2011 & $\begin{array}{l}\text { Sediment budget } \\
\text { Coastal morphodynamics } \\
\text { Hazard-zonation mapping }\end{array}$ \\
\hline & & West Bengal and Orissa (India) & $(1973-2000)$ \\
\hline & \multirow{2}{*}{$\begin{array}{l}\text { ISODATA classification of } \\
\text { image difference and ratios } \\
\text { of NIR and SWIR }\end{array}$} & Ekercin 2007 & Assessment of erosion/accretion \\
\hline & & Aegean Sea (Turkey) & $(1975-2001)$ \\
\hline \multirow{6}{*}{ Algorithm } & \multirow{2}{*}{ Slope } & Liu et al. 2013 & Assessment of waterline change \\
\hline & & The Yellow River Delta (China) & $(1973-2009)$ \\
\hline & \multirow[b]{2}{*}{ Sub-pixel algorithm } & Pardo-Pascual et al. 2012 & Shoreline identification \\
\hline & & $\begin{array}{l}\text { Castellón de la Plana and } \\
\text { Borriana (Spain) }\end{array}$ & $(1984-2002)$ \\
\hline & \multirow{2}{*}{$\begin{array}{l}\text { Binary segmentation NDWI } \\
\text { threshold }\end{array}$} & Kuleli et al. 2010 & Assessment of shoreline change \\
\hline & & Ramsar wetlands (Turkey) & $(1972-2009)$ \\
\hline
\end{tabular}

Noting the technical and methodological developments in Table 1, intuitive techniques such as manual digitization after visual identification have been increasingly superseded by automated methods intended to reduce human subjectivity and bias, as well as offering opportunities for cost savings. Multispectral optical sensors recording data in the visible range, but also in the near-infrared (NIR) and shortwave infrared (SWIR) wavelengths provide spectral combinations that clearly identify 
the water-land boundary (at a specific moment in time) for definition of the coastline. Examples of spectral indices (i.e. algebraic combinations of spectral bands) enhancing water features include the Normalized Difference Water Index (NDWI) (McFeeters, 1996) and the Modified NDWI (Xu, 2006). Capitalizing on the relationship between spectral response and land cover types, image classification algorithms are well established. Classification approaches have variable levels of analyst involvement (supervised or unsupervised classification) and options for the rigidity of the classification scheme (soft versus hard classification). The adequacy of each method and its successful implementation depends on multiple factors and requires local testing. Recently developed algorithms are being applied and demonstrated to identify linear features on the coast with very high spatial precision (Pardo-Pascual et al., 2012) and to support long term monitoring of detailed patterns of change detectable from a temporal series of co-located imagery (Lyons et al., 2012). Tradeoffs imposed by research conditions (e.g. data availability, consistency, and cost versus precision) make Landsat data an appropriate source of data for analysis of recent historical change.

\section{Methods}

\section{Study Area in the Outer Hebrides of Scotland: South Uist and Benbecula}

South Uist and Benbecula are two of the major islands of the Outer Hebrides archipelago, with a dispersed coastal population of ca. 3000 (Figure 1). The relief of the Atlantic margin is characterised by broad sub-horizontal areas of Lewisian gneiss bedrock overlain by a thin veneer of glacial drift. Along the Atlantic coastal margin this bedrock surface is mantled by a narrow strip of coastal dunes vegetated mainly with marram grass (Ammophila sp.) (Dickinson and Randall, 1979) and continued landward by broad vegetated areas of wind-blown carbonate-rich shell sand known as machair (Ritchie, 1972). The fertile nature of the machair soils has supported agriculture and grazing activities for centuries and it is home to numerous birds and plant species (Caird, 1979) conferring it a protection status under a series of international directives (Pakeman et al., 2011). 

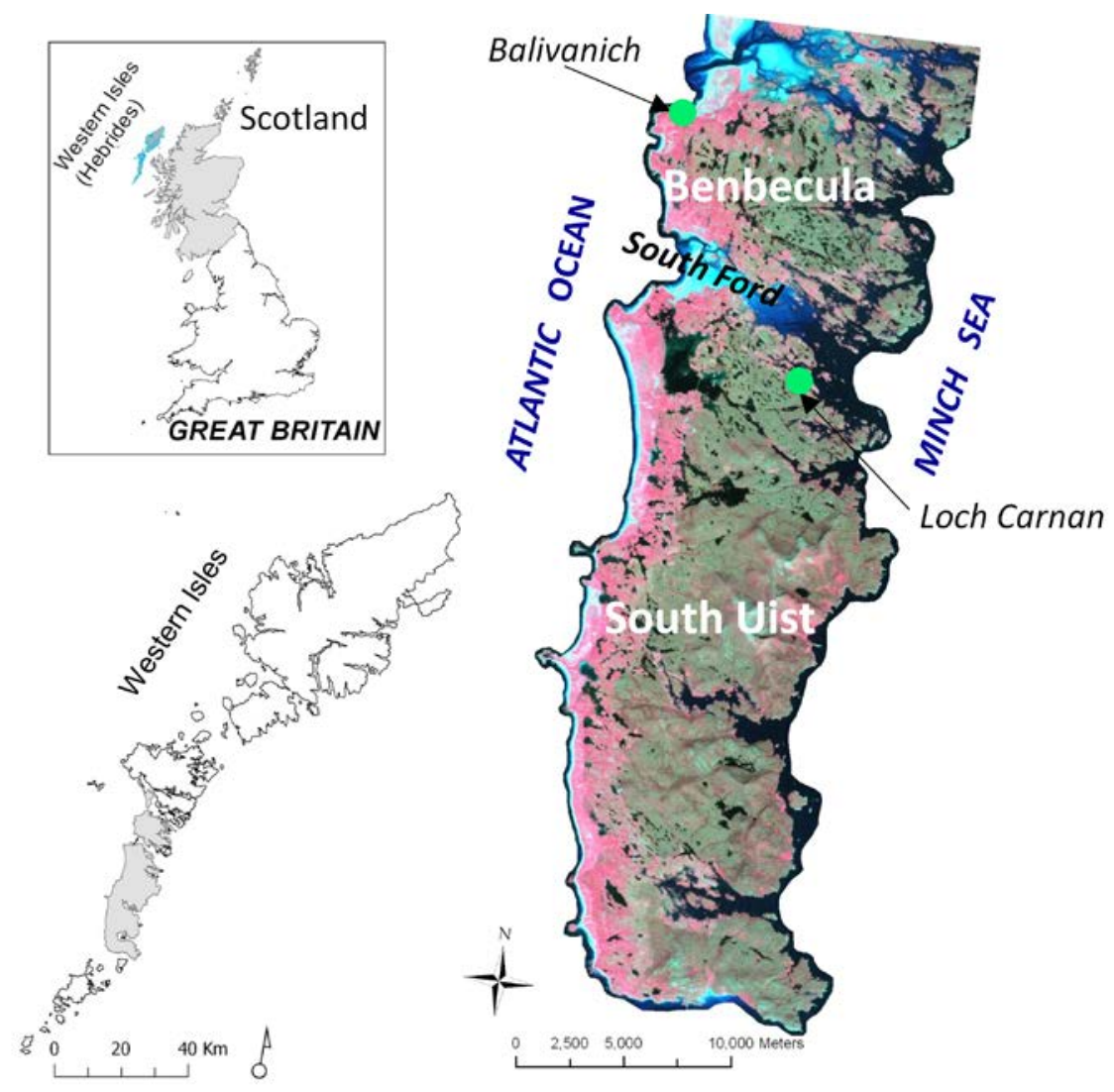

Figure 1. Location of study area: South Uist and Benbecula are two of the major Outer Hebrides in Scotland (UK). Visualization of Landsat image with band combination R/G/B: NIR, red, green. Relevant points marked in the image are mentioned in the text.

Between Benbecula and South Uist lies the South Ford, a sand-filled tidal strait protected from the full force of the Atlantic waves by a barrier island (Gualan). The Minch tide on the East has a maximum range of $4.5 \mathrm{~m}$ and is a few minutes ahead of the Atlantic tide on the West, which has a maximum range of $5.1 \mathrm{~m}$. Prevailing winds are predominantly from the S and SW (Ritchie, 1968), associated with waves that are frequently developed along the southern flank of Atlantic cyclones (Lozano et al., 2004; Dawson et al., 2007b).

\section{Data and Methods used}

The Landsat program has the longest historical archive of MSR imagery, with first captures occuring in 1972 and continuity provided by the successful launch of Landsat 8 in February 11, 2013. South Uist and Benbecula are completely encompassed within one Landsat scene, identified by WRS2 path/row 208/20, with the area also imaged in scene 207/020 as a consequence of image overlap. Four images recorded during period 1989-2011 were downloaded from www.glovis.usgs.gov, in a 
radiometrically calibrated and geographically referenced form (Table 2). Our image selection was guided to enable analysis of images with comparable characteristics: atmospheric condition, sun elevation, time of the year, and in particular tidal height and stage (e.g. rise, fall) at the time of image recording, which can be critical for processing and interpretation (Liu et al., 2013). Summer-time images were chosen to minimize detection of changes due to natural seasonality (Table 2).

Table 2. Landsat images used in the study and estimated tide status. On the Minch side (East) the tide is known to occur a few minutes earlier than on the Atlantic coast (West). Tide elevation was estimated by linear interpolation of astronomical predictions in Loch Carnan and Balivanich, and adjusted by atmospheric pressure.

\begin{tabular}{|c|c|c|c|c|c|c|}
\hline \multirow[b]{2}{*}{$\begin{array}{c}\text { Acquisition } \\
\text { date } \\
\text { (dd/mm/yyyy) }\end{array}$} & \multirow[b]{2}{*}{$\begin{array}{l}\text { Satellite } \\
\text { (Sensor) }\end{array}$} & \multirow[b]{2}{*}{ Path/Row } & \multirow[b]{2}{*}{$\begin{array}{c}\text { Sun elevation } \\
\left({ }^{\circ}\right)\end{array}$} & \multirow[b]{2}{*}{$\begin{array}{l}\text { Acquisition } \\
\text { time (GMT) }\end{array}$} & \multicolumn{2}{|c|}{ Tide (m OD) } \\
\hline & & & & & $\begin{array}{c}\text { Atlantic } \\
\text { (Balivanich) }\end{array}$ & $\begin{array}{l}\text { Minch } \\
\text { (Loch } \\
\text { Carnan) }\end{array}$ \\
\hline \multirow{2}{*}{ 11/09/1989 } & \multirow{2}{*}{ L5 (TM) } & \multirow{2}{*}{$207 / 20$} & \multirow{2}{*}{34.0} & \multirow{2}{*}{$9: 28$} & 1.62 & 1.99 \\
\hline & & & & & \multicolumn{2}{|c|}{ Rise } \\
\hline \multirow{2}{*}{ 18/08/1995 } & \multirow{2}{*}{ L5 (TM) } & \multirow{2}{*}{$208 / 20$} & \multirow{2}{*}{40.0} & \multirow{2}{*}{$\sim 11(* *)$} & 2.75 & 2.83 \\
\hline & & & & & \multicolumn{2}{|c|}{ Rise } \\
\hline \multirow{2}{*}{ 16/07/2003 } & \multirow{2}{*}{ L5 (TM) } & \multirow{2}{*}{$208 / 20$} & \multirow{2}{*}{50.8} & \multirow{2}{*}{ 11:04 } & 2.29 & 2.66 \\
\hline & & & & & \multicolumn{2}{|c|}{ Falling } \\
\hline \multirow[t]{2}{*}{ 03/05/2011 } & \multirow{2}{*}{ L5 (TM) } & \multirow{2}{*}{$208 / 20$} & \multirow{2}{*}{46.6} & \multirow{2}{*}{ 11:17 } & 2.30 & 2.05 \\
\hline & & & & & \multicolumn{2}{|c|}{ Falling } \\
\hline
\end{tabular}

Notes. L5 (TM): Landsat 5 (Thematic Mapper). GMT: Greenwich Meridian Time. (*) Time of image acquisition not specified in metadata and estimated as per scene standards.

During its more than forty years of history, the specifications of Landsat sensors have improved to achieve user data requirements. The spectral characteristics of Thematic Mapper (TM) imagery used in the present study, and the Operational Land Imager (OLI) onboard Landsat 8 are presented in Table 3. Landsat images (pixels sized: $15 \mathrm{~m}$ panchromatic, $30 \mathrm{~m}$ multispectral, and $60 \mathrm{~m}$ thermal) may be captured for each terrestrial location every 16 days, with data recorded in bands over different parts of the visible, infrared and thermal parts of the electromagnetic spectrum. The actual imaging of a given location is driven by a long term acquisition plan (Arvidson et al., 2006) required to maximize satellite on-board storage and down-link capacity, among other technical considerations. Of particular interest to coastal studies, the OLI includes an new "coastal band" in the ultra-blue, specified for water and near water features (Irons et al., 2012) that will offer improved detection of the land-water boundary (Pahlevan and Schott, 2012). 
Table 3. Optical spectral bands of Landsat sensors: TM (Thematic Mapper) used in this study and OLI (Operational Land Imager) launched 11 February 2013 and expected operational May 2013. GSD (Ground Sample Distance). The TM band 6 records thermal data with 120 m GSD; OLI has a companion sensor onboard L8 with two thermal bands.

\begin{tabular}{ccccccc}
\hline & TM & & & \multicolumn{3}{c}{ OLI } \\
\hline Number & Band width $(\mu \mathrm{m})$ & GSD $(\mathrm{m})$ & & Number & Band width $(\mu \mathrm{m})$ & GSD $(\mathrm{m})$ \\
\hline & & & & 1 & $0.43-0.45$ & 30 \\
1 & $0.45-0.52$ & 30 & Visible & 2 & $0.45-0.51$ & 30 \\
2 & $0.52-0.60$ & 30 & & 3 & $0.52-0.60$ & 30 \\
3 & $0.63-0.69$ & 30 & & 4 & $0.63-0.68$ & 30 \\
\hline 4 & $0.76-0.90$ & 30 & NIR & 5 & $0.84-0.88$ & 30 \\
\hline 5 & $1.55-1.75$ & 30 & \multirow{2}{*}{ SWIR } & 6 & $1.56-1.66$ & 30 \\
7 & $2.08-2.35$ & 30 & & 7 & $2.10-2.30$ & 30 \\
\hline & & & Panchromatic & 8 & $0.50-0.68$ & 15 \\
\hline
\end{tabular}

Notes. NIR: near infrared; SWIR: shortwave infrared

For accurate comparison of images captured at different dates and to detect real change avoiding misinterpretation of spurious artefacts, precise processing is vital, including correction of temporally variable atmospheric effects, radiometric normalization, and spatial registration. We applied standard techniques in the pre-processing of imagery (Table 4). The image recorded in July 2003, with clear atmosphere and average atmospheric pressure (1010.8 mb) served as reference for normalization.

The best possible determination of the tidal status at the time of image acquisition was based on astronomical tidal height predictions provided by the UK Hydrographic Office (UKHO) (www.easytide.com). UKHO provides expected high and low water values, in metres referred to Chart Datum, and the time they are likely to occur. To account for meteorological conditions, morning (9.00 am) atmospheric pressure readings at Stornoway meteorological station (UK meteorological services) on image acquisition dates were used. Astronomical tidal height predictions were adjusted by $1 \mathrm{~cm}$ per mb of extra pressure over $1013 \mathrm{mb}$ (high atmospheric pressure is associated with lower water height and vice versa). Records of moderate or low wind velocity registered at South Uist rocket station indicated no need to adjust for wind effects. 
Table 4. Processing stages of the Landsat images

\begin{tabular}{l|l}
\hline Process & Comment \\
\hline \multirow{2}{*}{ Download } & $\begin{array}{l}\text { USGS website (Woodcock et al., 2008) } \\
\text { Format L1T (standard terrain corrected format) }\end{array}$ \\
\hline Radiometric calibration & Spectral transformation to surface reflectance (Chander et al., 2009) \\
\hline \multirow{3}{*}{ Atmospheric correction } & $\begin{array}{l}\text { Semi-automatic cloud mask } \\
\text { Atmospheric correction of reference image with COST model (Chavez, 1988) in } \\
\text { ERDAS Imagine }\end{array}$ \\
\hline \multirow{3}{*}{ Geometric calibration } & $\begin{array}{l}\text { Reference image registered to Ordnance Survey (1:25000) maps (RMSE<1 } \\
\text { pixel) } \\
\text { Co-registration (RMSE }<0.5 \text { pixel) } \\
\text { Re-sampling with nearest neighbour algorithm } \\
\text { Location checked against contemporary aerial photography }\end{array}$ \\
\hline Subset & $\begin{array}{l}\text { Relative normalization of all images to the reference: IR-MAD in Matlab (Canty } \\
\text { and Nielsen, 2008; Nielsen, 2007 ) }\end{array}$ \\
\hline \multirow{2}{*}{ Spectral indices } & Raster clip to area of interest \\
& Ratio B5/B3= SWIR1 / Red \\
& $\begin{array}{l}\text { NDVI (Normalized Difference Vegetation Index) } \\
\text { NDVI = NIR - Red / NIR + Red }\end{array}$ \\
& $\begin{array}{l}\text { MNDWI (Modified Normalized Difference Water Index) } \\
\text { MNDWI = Green - SWIR / Green + SWIR }\end{array}$ \\
\hline
\end{tabular}

\section{Identification of Spectral Signatures for Land-cover Classification}

Land cover classification complexity is typically linked to the objectives for the use of the map, with broad categories often creating a framework to populate with more subtly differenced classes. Hierarchical classifications can support a categorically exhaustive set of classes whilst also allowing for additional effort to provide greater nested categorical detail for classes of interest. Vegetation, water, and bare soil are the three major land cover classes in the area. These classes also possess distinctive spectral signatures in the Landsat imagery. Healthy dense vegetation is characterized by low reflectance in the visible and SWIR, and high reflectance in the NIR, water is recognized by high reflectance in the visible blue and higher absorption in all other Landsat bands. Calcareous soils show relatively high reflectivity in the visible, varying with humidity, and variable response in the NIR and SWIR also as a function of humidity. Hard rock in headlands (unlikely to change) and shingle in beaches are calcareous, and show a spectral signature like that of the sand class. Hence, for the purpose of this work a combined class of bare soil (sand) was considered. The natural transitions between main classes (e.g. shallow water, wet sand, and sandy grassland) define spectrally different categories for which identification is possible with band combinations known as spectral indices. For instance the 
Ratio B5/B3 (SWIR1/Red) provides useful information for discrimination of dry sand $(0<$ Ratio B5/B3 < 1) from any type of vegetation (Ratio B5/B3 >1), and it also separates wet sand (Ratio B5/B3 $<0$ ) from shallow or deep water (Ratio B5/B3 > 0) (Figure 2). The Normalized Difference Vegetation Index (NDVI) and the Modified Normalized Difference Water Index (MNDWI) (Table 4) are established means for discrimination of vegetation types and identification of the water-land boundary respectively. Some of the subtle land-cover differentiations mentioned above are crucial for interpretation of coastal landscape change.

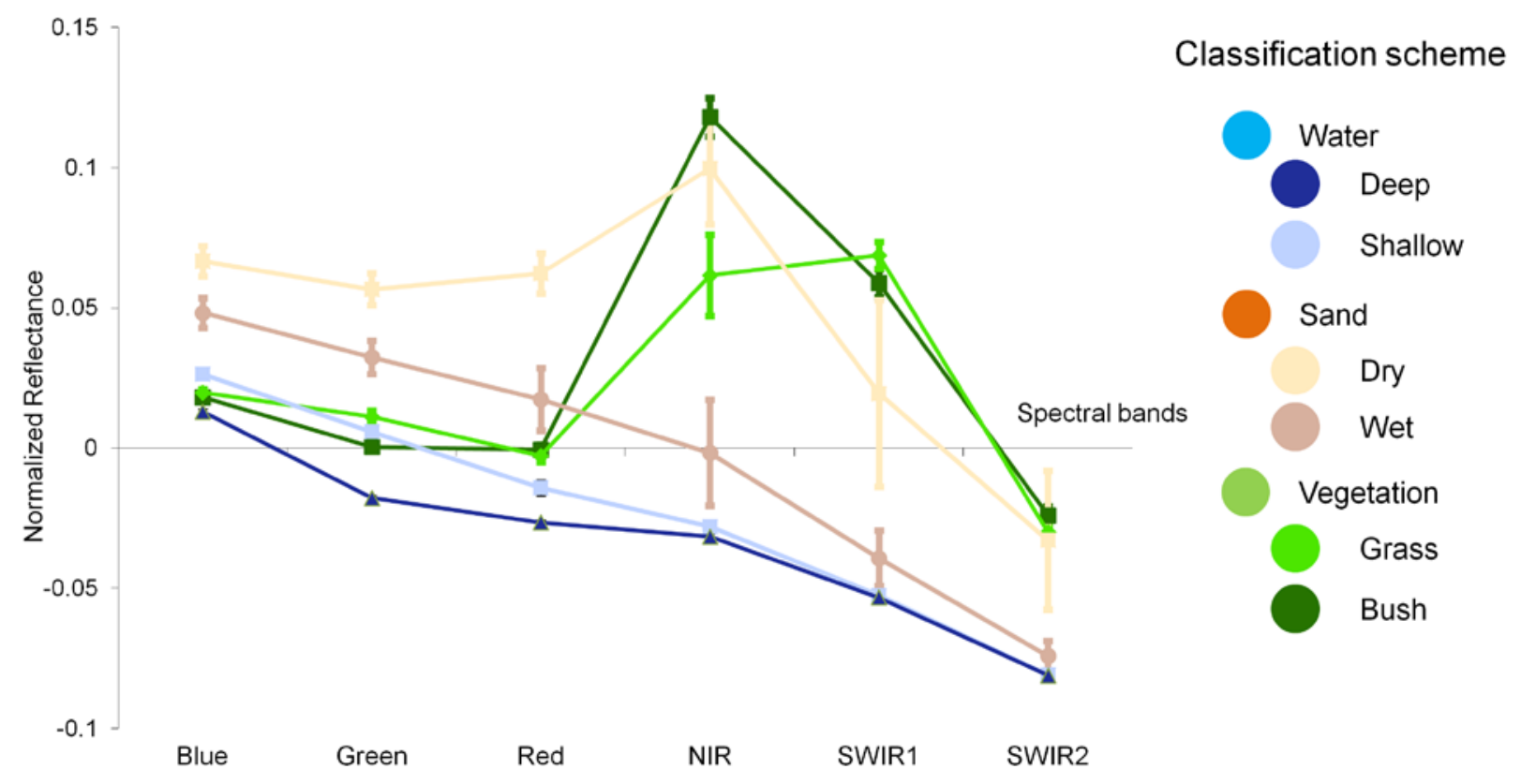

Figure 2. Left: Spectral signatures of the lower level classes as captured by Landsat images and standard deviation of samples used for determination. Centre: Map displaying coastal units of analysis (numbers are mentioned in text). Right: Dual level hierarchical classification scheme used in the study.

To fully exploit the information provided by land cover and transitions over time, a hierarchical classification scheme with six elemental categories in the bottom level under the three major covers was developed (Figure 2, right) and a supervised nearest neighbour (NN) classification algorithm was applied to each image individually. The spectral signatures and statistical parameters of the classification scheme were obtained from the reference 2003 data, which was classified first. Training samples were chosen through the entire area assuring any intra-class variability was captured, by visual inspection supported with contemporary aerial photography, which finer scale helped better identification of land cover. The NN classifier, based on the six reflective bands, the Ratio B5/B3, 
NDVI, and MNDWI (Table 4) was applied per pixel and trained with the spectral signature of samples acquired for the reference classification (i.e. year 2003 image), enforced by additional samples of vegetation for out of season images (1989 and 2010). The accuracy of the 2003 classification was checked with a standard process of point matching against aerial photography as reference information. Although lack of reference data at other dates prevented individual accuracy assessments, the process of radiometric normalization enforces the assumption of comparable results (Furby et al., 2008; Gómez et al., 2012). To evaluate the validity of the change maps trends of change identified in areas of 9 ha were checked by visual assessment against historical photography.

\section{Analysis of Change and Vulnerability}

Classified images were pair-wise compared and differences analysed for assessment of change over time, with consecutive layers of change enabling analysis of trends. While a pixel by pixel approach

provides spatially detailed information of the land cover transitions, zonal analysis enables the synthesis of spatial patterns that facilitate interpretation, reducing the impact of spatial or categorical error. On the Atlantic coastline of South Uist and Benbecula spatial units were defined for the analysis of coastal change and vulnerability by buffering a reference coastline $200 \mathrm{~m}$ inshore and $200 \mathrm{~m}$ offshore. The 2003 lower limit of land-based vegetation (here defined as the border of vegetation with any other class seawards) was used for this purpose. The global alongshore strip was split every $2 \mathrm{~km}$ of coastal stretch, generating forty nine spatial units.

A vulnerability indicator (VI) value was assigned to pixels that exhibited evidence of cover transitions that would eventually lead to permanent erosion or temporal flooding (Table 5). We infer here that a loss of vegetation to bare sand produced during a relatively short period of time (6-8 years) indicates an area at probable risk of later erosion (although care is needed to avoid misinterpretation of depositional sand), and also that areas of recent erosion correspond with areas where there has been a clear shift from vegetation to water. Derived vulnerability maps focused on land cover transitions listed in Table 5 with $\mathrm{VI} \leq 0$. 
Table 5. Potential land cover changes. Meaningful changes associated with vulnerability to erosion and flooding have negative VI value. VI values are qualitative indicators.

\begin{tabular}{cccc}
\hline \multicolumn{2}{c}{ Land cover (LC) transition } & \multicolumn{2}{c}{ Vulnerability } \\
\hline Initial LC & Final LC & State & Index (VI) \\
\hline \multirow{3}{*}{ Vegetation } & Vegetation & No change & 0 \\
\cline { 2 - 4 } & Sand & Vulnerable & -1 \\
\cline { 2 - 4 } & Water & Eroded & -2 \\
\hline \multirow{3}{*}{ Sand } & Vegetation & Vegetated & +1 \\
\cline { 2 - 4 } & Sand & No change & 0 \\
\cline { 2 - 4 } & Water & Flooded & -2 \\
\hline \multirow{2}{*}{ Water } & Vegetation & Vegetated & +2 \\
\cline { 2 - 4 } & Sand & Accreted & +1 \\
\cline { 2 - 4 } & Water & No change & 0 \\
\hline
\end{tabular}

Changes between the lower level classes are often indicative of transient processes and require additional information for interpretation, in particular knowledge of tidal conditions (height and stage) at the time of image recording. For example, a shift from wet sand to shallow water or vice versa can simply represent changes associated with a rise or fall in the tide. If tidal elevations were similar for each Landsat image, the same changes might reveal processes of sediment accumulation or loss.

\section{Evolution of the Shoreline}

To evaluate the evolution of coastal linear features the Digital Shoreline Analysis System (DSAS) was used. DSAS is an automated tool for statistical assessment of change in linear elements measured at various times (Thieler et al., 2009), particularly useful for evaluation of coastal retreat or accretion rates. A series of transects are cast at right angles from a defined baseline, and the points intersecting all target lines (e.g. chronological water lines) are used for calculation of distances and rates of change. We restricted this analysis to sandy beaches between Ardivachar and Vorran Island (Figure 3). The lower limit of land-based vegetation, often used as an indicator of the coastal edge (Boak and Turner, 2005) and independent of tide, was digitized and smoothed from each of the four classified images with a Polynomial Approximation with Exponential Kernel (PAEK) algorithm, removing the squaring raster effect and improving the line accuracy (Bodanskye et al., 2002). Transects were placed every 
$100 \mathrm{~m}$ along an inwards reference line (Thieler et al., 2009). In addition, a similar analysis was performed to evaluate the movement of the shallow water line, the boundary between beach sand and sea level. Variations of this line are indicative of alterations of the shape and volume of sediment along the profile of the shore. Since 2003 and 2011 images were recorded with similar tide conditions (both falling tide and with calculated $2.29 \mathrm{~m}$ and $2.30 \mathrm{~m}$ height, respectively, see Table 2), a displacement of this line hints to processes of sediment deposition (line moving offshore) or erosion (line moving onshore). In order to complement the data used in this analysis, the 1989 and 1995 shallow water line (derived from images captured at times with different tidal status) were included. The position of these lines was adjusted for tidal height difference making use of the local average slope of DTMs derived from aerial photography dated 1984 and 2005 (2 m spatial grain) (Gómez et al., 2008). The 1989 shallow water line was moved 12.6 m landwards and the 1995 line 8.3 m seawards.

Attributes of change calculated with the DSAS tool include: a line envelope of change (EC), which is the distance between the two most separated lines at each transect and represents the total movement of the linear feature; a net line movement (NM), indicated by the distance between the oldest and youngest lines; a linear regression rate of change (LRR).

\section{Results}

Four land cover maps (one per image date) and three maps of change (one per inter-image period) were produced. Following approval of quality by visual inspection, the accuracy of the reference classification (i.e. the 2003 image) was assessed with a standard procedure: 340 reference points randomly distributed were checked against contemporary aerial photography. A confusion matrix (Table 6) indicated 95\% overall accuracy and enabled identification of the error sources. Most misclassifications occurred between lower level adjacent classes (i.e. dry-wet sand, bush-grass vegetation), expected as a result of imperfect temporal coincidence of the reference and target data, but also due to non-anniversary imagery that could induce classification errors related with vegetation phenology or seasonal beach processes. Vegetation classes were not confused with water or sand in producing the map. However, as shown by the users' errors indicated by the ground truth sample, these classes (grass and bush) were over-mapped; in particular some errors identified by visual inspection were associated with the presence of seaweed. This type of mistake can be corrected by inclusion of contextual information in the classification algorithm. The wet sand class is the most difficult to 
identify with Landsat spectral data, and sometimes gets confused with dry sand and shallow water classes. Values of user and producer's error for the wet sand class are just over $10 \%$ and would affect the reliability of the shallow water line position.

Table 6. Accuracy matrix of the 2003 classification where sources of error are identified. Producer's and user's accuracy are typical measures of the error by omission and commission, respectively.

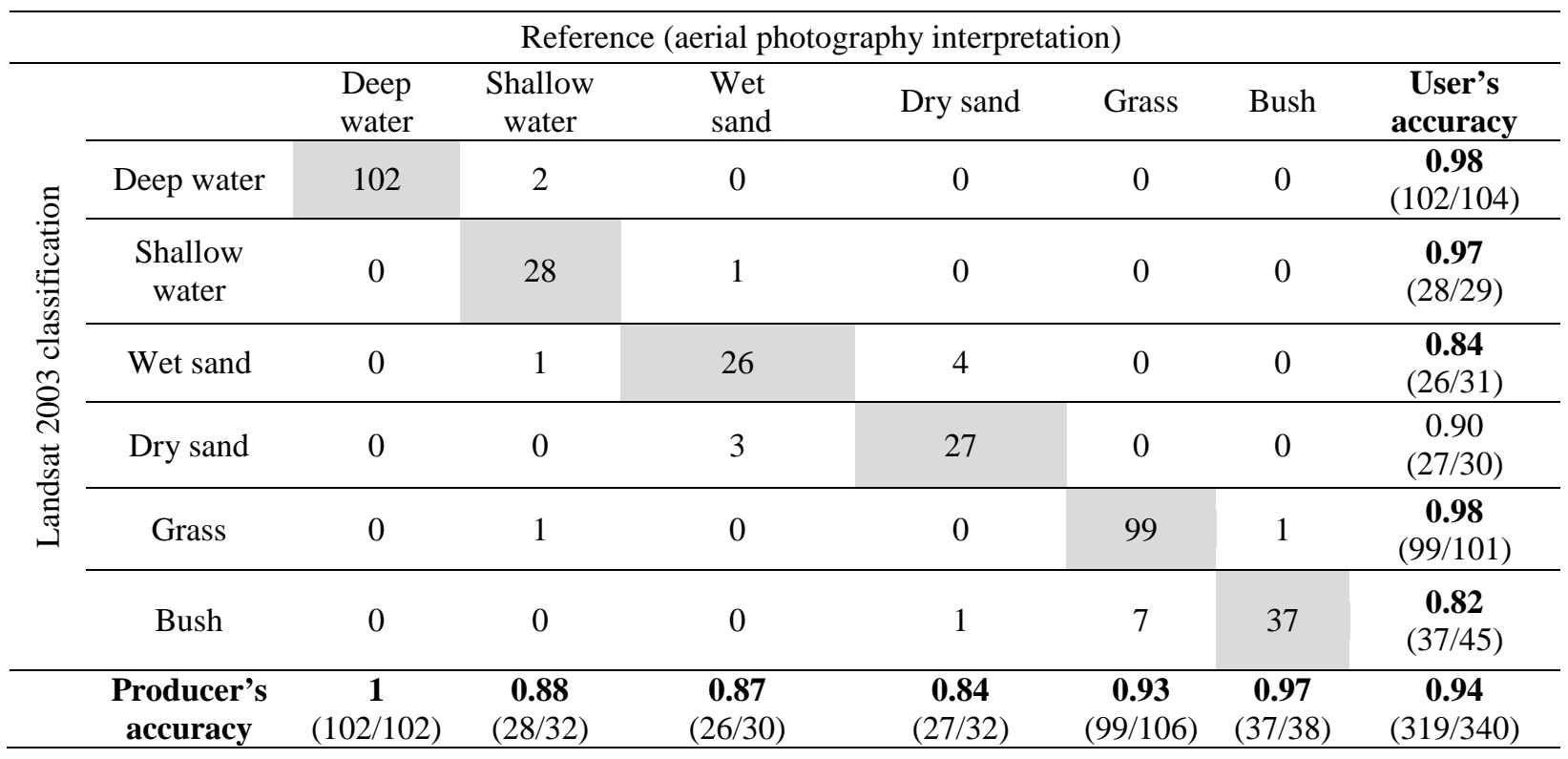

To assess correctness of the changing maps we verified trends of change with a series of historical (1942-1965) and recent $(1984,2005)$ aerial photography. A 10 x 10 Landsat pixel window was centred at locations with at least 3 overlapping aerial photos for visual validation of changing trends. From 50 areas checked, the analyst judged 47 trends of change/no change correctly identified by the Landsat change assessment. The three difficult locations were found to be partially covered by clouds in one of the images, confounding the classification result. The reliability of the vulnerability maps can only be partially verified, although we are able to use evidence in previous and later images to provide a check to verify change observed in later images.

\section{Land Cover, Land Cover Change, and Maps of Vulnerability}

The strip of coastal area analysed covers $35.5 \mathrm{~km}^{2}$, with each of the 49 shore subunits representing an area of $0.73 \mathrm{~km}^{2}$ (811 pixels). Considered as a whole, the shore appears as relatively stable over time in the proportion of its main land cover classes (vegetation, sand, and water) although there is evidence of a slight tendency to have lost vegetation in favour of exposed sand. The distribution of 
element fractions varies across individual shore units, implying a variety of coastline formations (Figure 3 left). The widest sand beaches (some of them backed by a ridge of shingle) are $190 \mathrm{~m}$ in units 21, 22, 23 (between Ardivachar and the Howmore estuarine), unit 1 (east of the southern tip of Baleshare island) and unit 38 (Boisdale), (Figure 3). In the southern area (units 45-49) pocket beaches have remained stable throughout the time interval. These have probably been protected from predominant wave driven currents by local topography and their overall southern orientation.

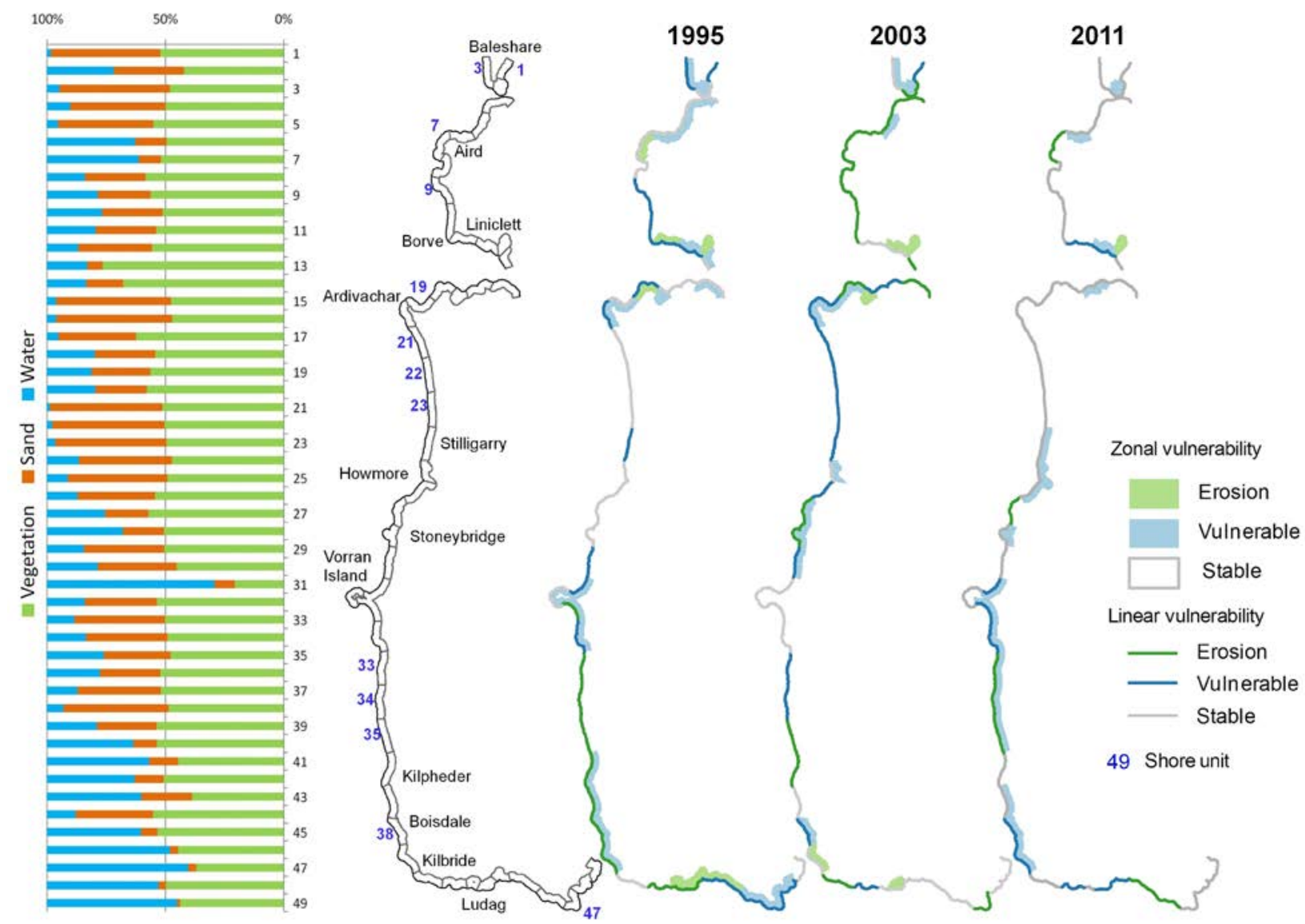

Figure 3. Left: Land cover fractions per shore unit averaged for period 1989-2011. Right: Maps of vulnerability in 1995, 2003, and 2011, as derived from maps of land cover change

Vulnerable locations identified with a pixel by pixel approach were summarized into the longshore units for representation (Figure 3) and globally for reporting (Table 7). A linear sequence of vulnerable pixels along the coastline (Figure 3) indicates instability of the front line, frequently related to periodic processes of loss and recovery of beach colonizer species like marram grass or sea rocket (Cackile maritima), adapted to harsh conditions and known for their capacity of fast colonization. Part of the coast of Benbecula was identified as vulnerable to erosion in 1995 and having experienced erosion by 
2003. By contrast, between Ardivachar and Stoneybridge an area identified as vulnerable in 2003 was relatively stable by 2011. Between Vorran Island and Kilbride erosion has been persistent for two decades, but was particularly intense before 1995. This find is of particular importance, since there has always been a concern that coastal retreat in Kilpheder may result in the breaching of coastal barriers and the flooding by the sea of large areas of machair (CREW, 2012).

The risk to erosion and flooding is most significant when a group of vulnerable pixels appear together. A shore unit was considered vulnerable when it held at least one cluster of 9 or more vulnerable ( $\mathrm{VI}<0$ ) pixels (Figure 3). We identified transformations related to the construction of the causeway from Ludag to Eriskay in 2000 as a region with erosion, and some areas identified as vulnerable pre-2003 were strongly affected by an exceptionally strong storm that occurred in 2005 (Dawson et al., 2007b).

Table 7. Summary of change in the shore area: number of transformed pixels and equivalent area (hectares) per basic land cover type and per period. Only de facto occurring changes are included.

\begin{tabular}{|c|c|c|c|c|}
\hline \multirow{2}{*}{ Land cover change } & \multirow{2}{*}{ Effect - Vulnerability } & \multicolumn{3}{|c|}{ Period } \\
\hline & & 1989-1995 & 1995-2003 & 2003-2011 \\
\hline Vegetation to Water & Erosion & $\begin{array}{c}399 \\
(35.91)\end{array}$ & $\begin{array}{c}230 \\
(20.70)\end{array}$ & $\begin{array}{c}246 \\
(22.14)\end{array}$ \\
\hline Vegetation to Sand & Vulnerable & $\begin{array}{c}1782 \\
(160.38)\end{array}$ & $\begin{array}{c}931 \\
83.79)\end{array}$ & $\begin{array}{c}1308 \\
(117.72)\end{array}$ \\
\hline Sand to Water & Erosion if persistent & $\begin{array}{c}1957 \\
(176.13)\end{array}$ & $\begin{array}{c}596 \\
(53.64)\end{array}$ & $\begin{array}{c}140 \\
(12.60)\end{array}$ \\
\hline Sand to Vegetation & Re-vegetation & $\begin{array}{c}639 \\
(57.51)\end{array}$ & $\begin{array}{c}1375 \\
(123.75)\end{array}$ & $\begin{array}{c}1290 \\
(116.10)\end{array}$ \\
\hline Water to Sand & Accretion if persistent & $\begin{array}{c}225 \\
(20.25)\end{array}$ & $\begin{array}{c}1016 \\
(91.44)\end{array}$ & $\begin{array}{c}1472 \\
(132.48) \\
\end{array}$ \\
\hline
\end{tabular}

An area of particular interest is the west side of South Ford, where significant variability of sediment accumulation is noted over the period (Figure 4, graph). For instance, in the 2003 image there were ca. $4.8 \mathrm{~km}^{2}$ (5338 pixels) of exposed sand, whereas in 2011, under similar tidal conditions this value had increased to ca. $6.9 \mathrm{~km}^{2}$ (7766 pixels). This result is in agreement with other studies (Dawson et al., 2012b; Rowan et al., 2010) and indicates a trend during the last few decades to accumulate sediment in the form of sand bars, that is in turn affecting circulation of water in predefined inter- and sub- tidal channels. 


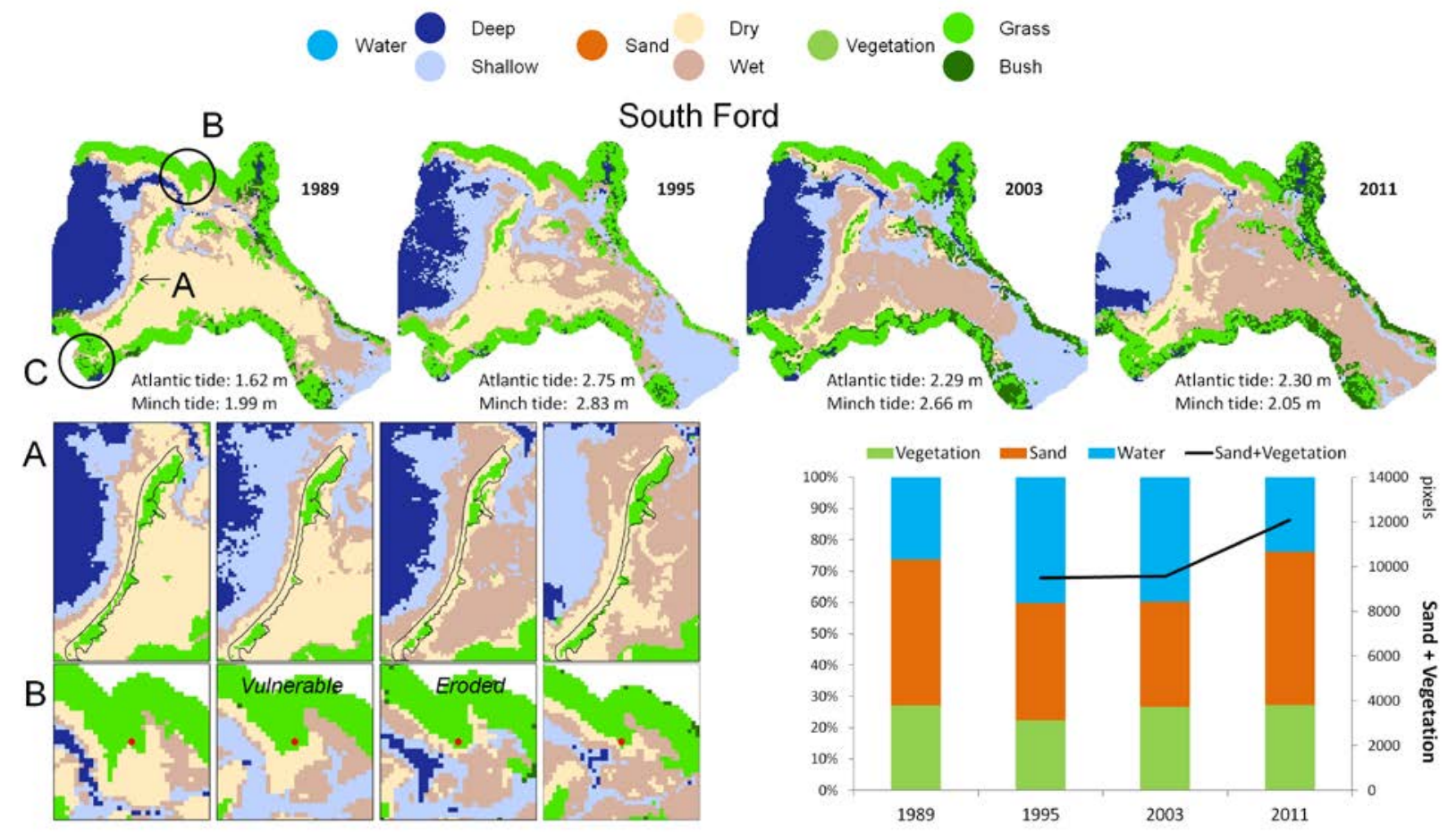

Figure 4. Top: Land cover maps of the South Ford at different dates; tide height on the Atlantic and on the Minch is indicated as relevant for interpretation. Bottom left: examples of morphology change mentioned in text (A: Gualan Island; B: Liniclett peninsula). Bottom right: fraction of land cover elements at each image time and amount of pixels identified as sand or vegetation

Some notable changes in the morphology of the basin are evident. Gualan island (Figure 4, A) was more stable in 1989, as indicated by a more extensive vegetation coverage (232 pixels in total, equivalent to $20.88 \mathrm{ha}$ ). In this area, however, the 1995 vulnerability map (derived from 1989-1995 change) depicts risk of erosion on the eastern and western faces of Gualan and is further supported by a measured minimum vegetation coverage of 10.35 ha in 2003.

The maps of vulnerability and change produced at each interval show significant coastal retreat across the Liniclett peninsula (Figure 4, B), first depicted as vulnerable in 1995. During the following period (1995-2003) 2.5 ha (28 pixels) of vegetation and sand were eroded by a north migrating tidal channel and possible wave erosion. Conversely, the area separating the southern end of Gualan island from South Uist (Figure 4, C) shows evidence of widespread sand accumulation since 1989. 


\section{Temporal Change of Shore Linear Elements}

Computing the data for 172 transects reveals that the envelope of change of the lower limit of landbased vegetation ( $\mathrm{EC}_{\text {vegetation}}$ ) between 1989-2011, is on average $30.6 \mathrm{~m}$, with a maximum of $106 \mathrm{~m}$ (south of Ardivachar, unit 21) and a minimum of zero $m$ at several points. The net shift of this line (seawards or landwards) is on average $8.8 \mathrm{~m}$. By subtracting net change from the envelope of change, the most active areas of change appear scattered along the coast (higher values of this parameter indicate less stability) (Figure 5). The statistically calculated rate of plannimetric displacement of the lower limit of land-based vegetation ( $\mathrm{LRR}_{\text {vegetation}}$ ) ranges from $-2.54 \mathrm{~m} \mathrm{y}^{-1}$ (maximum retreat) found at Stilligarry to $+4.13 \mathrm{~m} \mathrm{y}^{-1}$ (maximum seward progradation) found south of Ardivachar, with an average value close to zero $\left(0.3 \mathrm{~m} \mathrm{y}^{-1}\right)$.
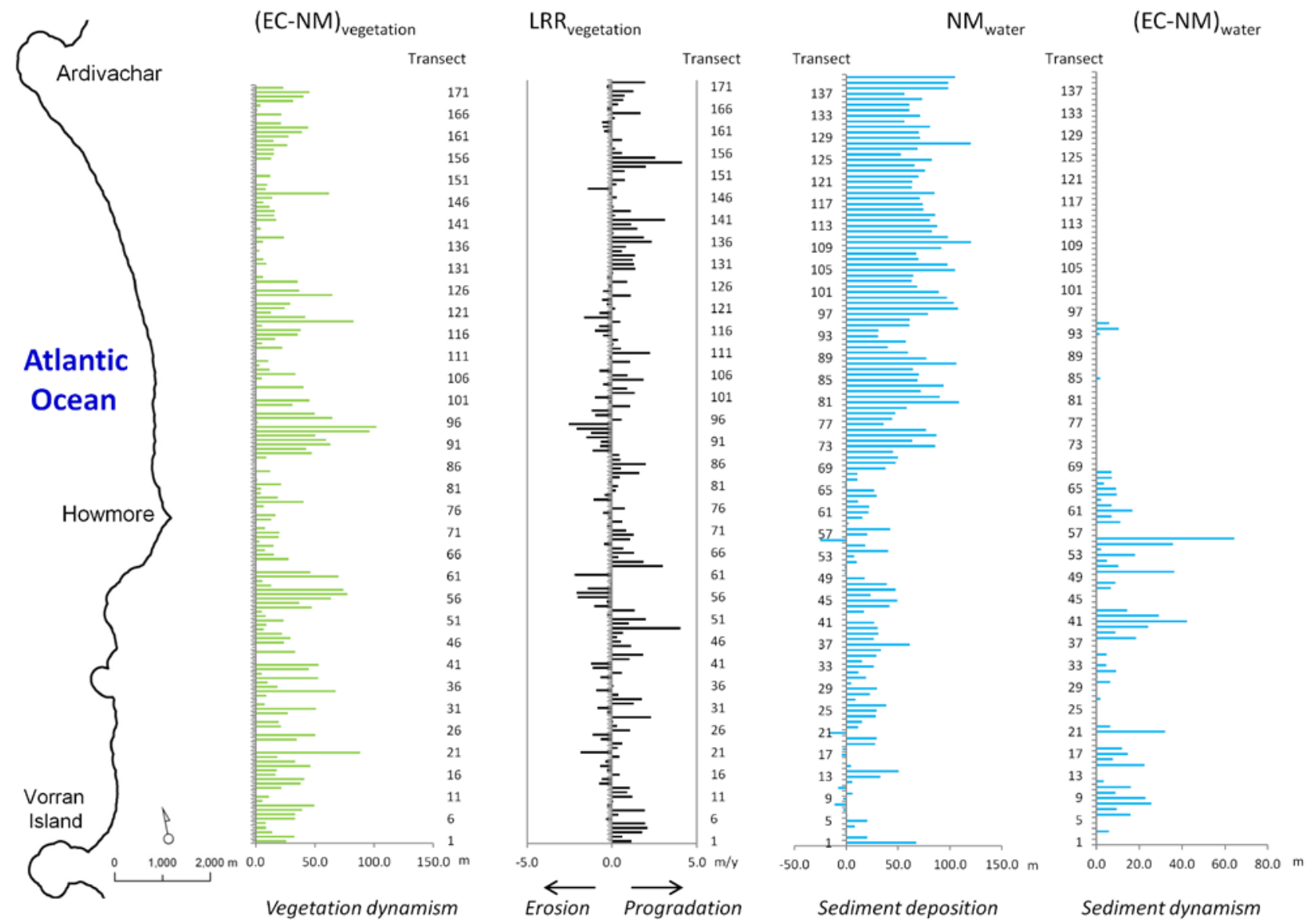

Figure 5. DSAS analysis of the vegetation and water line. EC (Envelope of change): distance between the two most separated lines at each transect. NM (Net line Movement): distance between the oldest and youngest lines. LRR (Linear Regression Rate): rate of change evaluated with linear regression. A.

$(\mathrm{EC}-\mathrm{NM})_{\text {vegetation: }}$ the difference between envelope of change and net movement shows the most 
dynamic areas. B. $L_{R R}$ vegetation: indicates the linear regression rate of shoreline movement. C. $\mathrm{NM}_{\text {water }}$ : net movement of shallow water line represents the net displacement of this line, associated with

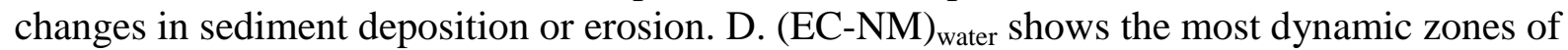
sediment circulation

In the case of the shallow water line (shallow water-exposed sand border) the displacement across 140 transects was calculated. The envelope of change of this line $\left(\mathrm{EC}_{\text {water }}\right)$ indicates an average seaward progradation of $51.1 \mathrm{~m}$, with a range between 2-120 m. The net movement (distance between line positions in 1989 and 2011) is on average $46.4 \mathrm{~m}$ (seawards) with the majority of the highest accretional values indicated for the coastal stretch between the Howmore estuary and Ardivachar (Figures 3 and 5). Overall, there appears to be a tendency, at least since 1989, of net accretion of sediments along the Atlantic coastlines of Benbecula and South Uist, as well as a possible movement of sand northward. Caution is needed in the interpretation of quantitative movements, as part of the assessed change is presumably due to remaining effects of seasonality-typically higher and wider beaches in summer and lower and narrower beaches in winter. However, the general trends reported here are in agreement with a recent study based on sedimentology and analysis of radio isotopes by Rowan et al. (2010). This concluded that the predominant direction of sediment transport in this area has been from South to North at least since the 1960s, confirming the results of several earlier studies (Ritchie, 1971, 1979).

\section{Discussion}

Archived Landsat imagery over South Uist and Benbecula for the period 1989-2011 enabled identification of dynamic patterns of change on the Hebridean Atlantic coastline, and highlighted particular areas that have been subject to significant coastal retreat, and areas that are vulnerable to coastal erosion and flooding. The study is the first of its kind for a Scottish coastal area and raises the possibility of applying the same methodology to the whole of Scotland's coastline (cf. Green et al., 1996; Huang and $\mathrm{Fu}$, 2002). Quantitative information on rates and patterns of change obtained by spatial and statistical analysis of land cover classification is consistent with field observations by other authors (Dawson et al., 2009, 2012b; Rowan et al., 2010). 


\section{On patterns of change}

The Atlantic shore of South Uist and Benbecula was generally stable during the period 1989-2011, in spite of frequent intermittent local areas of change, reflected by intermingled loss and gain of vegetation. It would appear that sea flooding linked to periodic storm surges originates small patches of land cover change, but appears not to have led to widespread net coastal land loss during the period of study. Conversely, extreme storm events such as occurred in January 2005 may trigger widespread modifications on the coast, with headlands experiencing the greatest change (Dawson et al. 2007b). At the temporal scale considered in this work, we identified cases of "permanent" instability in the stretch between Ardivachar and Vorran Island: the low lands between the beach and vegetated dunes appeared to alternate between being covered by aeolian sand depositions and vegetation. On the other hand, less rapid and volatile changes occurred in the South Ford basin. In this area, the Minch and Atlantic tides create a complex flux, ebb and flood water movements which changed progressively the course of the northern water discharge channel. In turn, this channel movement eroded and removed a formerly south-projecting sand tip area of 2.5 ha in Liniclett. According to Dawson et al. (2012b), this area accumulated abundant material in the form of dunes at least until the 1960s. This material must have moved somewhere else, e.g., into the intertidal basin. On the opposite end of the sand basin, south of Gualan Island, persistent sediment accumulation building a sandflat impedes tidal exchange between Loch Bee and the South Ford, and in the absence of water flow, ecological recovery with vegetation confirms the closing of the water exchange point (Figure 4, C). Medium and long term redistribution of materials moulds the basin morphology and accommodates water flows (Dawson et al., 2012b), with some apparent circulation processes of water and sediment still unexplained.

Evidence of persistent erosion on parts of Gualan, the barrier island protecting the South Ford from the Atlantic forces, concerns local people. Erosion here could break the barrier permanently and leave neighbouring coastal areas unprotected. The height of Gualan dune barrier ridge currently ranges between five and ten meters, but the central stretch is bereft of dunes and has a history of breaching events by the Atlantic waves (Dawson et al., 2012b). Change analysis based on Landsat imagery over the last decades (1989-2011) identifies a minimum vegetation cover of Gualan in 2003, and thus points to this time as the period of greatest vulnerability to erosion and breaching. Dawson et al. (2012b) identified a generalized retreat of the Atlantic coastline between 1984-2005 through a series of DEMs 
derived from Lidar measurements and stereo-photogrammetry. Indications of vulnerability depicted in the Landsat change maps for periods 1989-1995 and 1995-2003 provide a possible forecast of some effective retreat of the beach edge that is documented later. Since 2003, the southern part of Gualan has experienced sediment accumulation and vegetation growth. The Landsat imagery analysis indicates that this area (south of Gualan) corresponds with the greatest net sediment accumulation along the Atlantic coastline of South Uist and Benbecula.

\section{On opportunities to monitor recent coastal change with medium spatial resolution imagery}

Satellite Earth observation records exist for more than forty years, with spatial resolution suitable to detect coastal features, and frequent acquisitions to evaluate transformations over time. In addition to the Landsat program, other satellites with similar characteristics (Stoney, 2008) may complement the Landsat data holdings (Wulder et al., 2008). The US Geological Survey (USGS) holds an archive of now over four million images (1) freely available through a website portal since 2008 (Woodcock et al., 2008). The USGS is working to collect and add to the central archive images from International Co-operators such as the European Space Agency (ESA), which currently holds two million images. Recently reported information describes the ongoing release and sharing of imagery from ESA to USGS (2).

Detecting short duration land cover transitions is possible with frequent imagery that in turn has capacity to detect subtle changes. A wider temporal window is enough to measure permanent change and just a few images acquired at an appropriate time interval provide essential information of change if the methodology used is sufficiently robust. If intense monitoring is necessary, recent studies have shown ability for identification of finer patterns of change by incorporating annual imagery (Lyons et al., 2012). Use of enhanced computing facilities and techniques, to systematically remove clouds and shadows (Zhu and Woodcock, 2012), encourage the inclusion of more imagery in studies of change. This allows more detailed information to be extracted.

The pixel-by-pixel post-classification analysis of change has some known limitations related to compounding of classification error present for individual dates (Fuller et al., 2003). These issues can be overcome through spatial aggregation of classes and description of more generalized trends (as we implemented in this research), whereby a pixel-to-pixel differencing is not undertaken or implied. 
Alternative methods for detection of land cover change with multi-date spectral information exist (e.g. spectral change detection). These have the potential to provide increased reliability of spatial and categorical outcomes. For precise location of coastal linear features, and to detect small coastal movements over time, emerging algorithms such as gradient analysis (Kachouie et al., 2013), subpixel feature extraction (Pardo-Pascual et al., 2012) or soft classification (Muslim et al., 2007) are promising options. The radiometry of OLI, the optical sensor onboard Landsat 8 (Irons et al., 2012) has been improved to 12 bit. OLI also includesa new ultra blue band that is optimized for aquatic ecosystems (Gerace and Schott, 2009), outperforming early generations of the Landsat sensors (MSS, TM and ETM+) which were not optimized for aquatic ecosystems (Sass et al., 2007). Further operational missions are intended to follow (Loveland and Dwyer, 2012) aimed at providing continuity of complementary and calibrated measures. The Sentinel-2 satellites of the ESA will collect data similar to the Landsat series of satellites, augmented by refinements to spatial, spectral, radiometric, and temporal resolutions (Drusch et al., 2012). Notably, Sentinel-2 is planned to be a two sensor constellation, off-setting two satellites in the same orbit to shorten the revisit and increase the opportunity to obtain cloud free imagery. A large imaging footprint (image size per acquisition) will also aid the collection of data for desired time periods and free of clouds.

\section{Conclusion}

Although some limitations are recognized in relation to the positional accuracy of linear features, archived and recent medium spatial resolution remotely sensed imagery provided valuable information to identify patterns of transient and persistent change in the Atlantic coast of two Scottish islands. Trends in sediment movement were observed and areas subject to recent morphological change were identified. The study highlights opportunities for assessment of change in coastal environments at temporal and spatial scales relevant to human actions and management activities using Landsat imagery.

\section{Notes:}

(1) http://www.landsat.usgs.gov

(2) http://www.esa.int/Our_Activities/Observing_the_Earth/New_Landsat_data_just_a_few_clicks_away 


\section{References:}

Angus, S. \& Hansom, J.D. (2004) Tir a'mhachair, tir nan loch? Climate change scenarios for Scottish machair systems: A wet future? In: Green, D.R. (ed.) Delivering Sustainable Coasts: Connecting Science and Policy. Littoral 2004. Aberdeen, Scotland, UK, September 2004. pp. 565-569.

Arvidson, T., Goward, S., Gasch, J. \& Williams, D. (2006) Landsat-7 Long-Term Acquisition Plan: Development and Validation, Photogrammetric Engineering and Remote Sensing, 72, pp. 11371146

Boak, E.H. \& Turner, I.L. (2005) Shoreline definition and detection: a review, Journal of Coastal Research, 21, 4, pp. 688-703.

Burak, S., Doğan, E. \& Gazioğlu, C. (2004) Impact of urbanization and tourism on coastal environment, International Journal of Remote Sensing, 47, pp. 515-527.

Caird, J.B. (1979) Land use in the Uists since 1800, Proceedings of the Royal Society of Edinburgh. Section B. Biological Sciences, 77, 505-526. doi:10.1017/S0269727000012884

Canty, M.J. \& Nielsen, A.A. (2008) Automatic Radiometric Normalization of Multitemporal Satellite Imagery with the Iteratively Re-weighted MAD Transformation, Remote Sensing of Environment, 112, pp. 1025-1036.

Carter, R.W.G. (1989) Coastal environments: an introduction to the physical, ecological, and cultural systems of coastlines, Academic Press, London.

Cazenave, A. \& Nerem, R.S. (2004) Present-day sea level change: observations and causes, Reviews of Geophysics, 42, pp. 1-20.

Chander, G., Markham, B.L. \& Helder, D.H. (2009) Summary of current radiometric calibration coefficients for Landsat MSS, TM, ETM+, and EO-1 ALI sensors, Remote Sensing of Environment, 113, pp. 893-903.

Chatenoux, B. \& Peduzzi, P. (2007) Impacts from the 2004 Indian Ocean Tsunami: analyzing the potential protecting role of environmental features, Natural Hazards, 40, pp. 289-304.

Chávez, P.S. (1988) An improved dark object subtraction technique for atmospheric scattering correction of multispectral data, Remote Sensing of Environment, 24, 459-479.

Church, J.A. \& White, N.J. (2006) A 20th century acceleration in global sea-level rise, Geophysics Research Letters, 33, L01602, doi:10.1029/2005GL024826 
CREW (2012) Coastal flooding in Scotland: A guidance document for coastal practitioners. The James Hutton Institute, Aberdeen, Scotland, UK.

Dawson, A.G., Ritchie, W.A., Green, D., Wright, R., Gómez, C. \& Taylor, A. (2007a) Assessment of the rates and causes of change in Scotland's beaches and dunes-Phase 2. Commissioned Report for Scottish Natural Heritage, 214 pp.

Dawson, A.G., Dawson, S. \& Ritchie, W. (2007b) Historical climatology and coastal change associated with the "Great Storm" of January 2005, South Uist and Benbecula, Scottish Outer Hebrides, Scottish Geographical Journal, 123, pp. 135-149.

Dawson, A.G., Gómez, C. \& Ritchie, W. (2009) Quantification of the physical changes in the coastal landscape of the South Ford, Outer Hebrides. Commissioned report for Comhairle nan Eilan Siar, South Ford Hydrodynamics Study, June 2009, 43 pp.

Dawson, A.G., Dawson, S., Cooper, A., Gemmel, A. \& Bates, R. (2012a) A Pliocene age and origin for the strandflat of the Western Isles of Scotland: a speculative hypothesis, Geological Magazine, doi:10.1017/S0016756812000568

Dawson, A.G., Gómez, C., Ritchie, W., Batstone, C., Lawless, M., Rowan, J.S., Dawson, S., McIlveny, J., Bates, R. \& Muir, D. (2012b) Barrier Island Geomorphology, Hydrodynamic Modelling, and Historical Shoreline Changes: An Example from South Uist and Benbecula, Scottish Outer Hebrides, Journal of Coastal Research, 28, pp. 1462-1476 doi:10.2112/JCOASTRES-D-11-00184.1

Delaune, R.D., Patrick, W.H. \& Buresh, R.J. (1978) Sedimentation rates determined by 137Cs dating in a rapidly accreting salt marsh, Nature, 275, pp. 532-533.

Desprats, J.F., Gracin, M., Attanayake, N., Pedreros, R., Siriwardana, C., Fontaine, M., Fernando, S. \& De Silva, U. (2010) A coastal hazard GIS for Sri Lanka, Journal of Coastal Conservation, 14, pp. 21-31.

Devoy, R.J. (1987). Sea-level changes during the Holocene: the North Atlantic and Arctic Oceans, In: Devoy RJN (ed) Sea surface studies. Crom Helm Beckenham, pp. 294-347.

Dewidar, K.M. \& Frihy, O.E. (2010) Automated techniques for quantification of beach change rates using Landsat series along the North-eastern Nile Delta, Egypt, Journal of Oceanography and Marine Science, 1, pp. 28-39. 
Dickinson, G. \& Randall, R.E. (1979) An interpretation of machair vegetation. Proceedings of the Royal Society of Edinburgh 77B, pp. 267-278.

Drusch, M., Del Bello, U., Carlier, S., Colin, O., Fernandez, V., Gascon, F., Hoersch, B., Isola, C., Laberinti, P., Martimort, P., Meygret, A., Spoto, F., Sy, O., Marchese, F. \& Bargellini, P. (2012) Sentinel-2: ESA's Optical High-Resolution Mission for GMES Operational Services, Remote Sensing of Environment, 120, 25-36. doi: 10.1016/j.rse.2011.11.026.

El-Asmar, H.M. \& Hercher, M.E. (2010) Change detection of the coastal zone east of the Nile Delta using remote sensing, Environmental Earth Science, 62, pp. 769-777.

Fuller, R. M., Smith, G. M., Devereux, B. J. 2003. The Characterisation and Measurement of Land Cover Change through Remote Sensing: Problems in Operational Applications? International Journal of Applied Earth Observation, 4, 243-253.

Furby, S.L., Caccetta, P.A., Wu, X. \& Chia, J. (2008) Continental scale land cover change monitoring in Australia using Landsat imagery. Earth Conference-Studying Modeling and Sense Making of Planet Earth, 1-6 June, Department of Geography, University of the Aegean, Mytilene, Lesvos, Greece (2008).

Gerace, A. \& Schott, J. (2009) The increased potential for the Landsat Data Continuity Mission to contribute to case 2 water quality studies. Earth Observing Systems XIV, edited by James J. Butler, Xiaoxiong Xiong, Xingfa Gu. Proc. of SPIE Vol. 7452, 74520U doi: 10.1117/12.825271

Gómez, C., Taylor, A., Green, D., Ritchie, W., Dawson, A. \& Wright, R. (2008) Terrain 3D modelling for the assessment of coastal change in beach and dune systems in Scotland, Society of Cartographers Bulletin, 42, pp. 21-28.

Gómez, C., Wulder, M.A., White, J.C., Montes, F. \& Delgado, J.A. (2012) Characterizing 25 years of change in the area, distribution, and carbon stock of Mediterranean pines in Central Spain, International Journal of Remote Sensing, 33, pp. 5546-5573.

Green, E.P., Mumby, P.J., Edwards, A. J. \& Clark, C.D. (1996) A review of remote sensing for the assessment and management of tropical coastal resources, Coastal Management, 24, pp. 1-40. DOI: $10.1080 / 08920759609362279$

Huang, W. \& Fu, B. (2002) Remote sensing for coastal area management in China, Coastal Management, 30, pp. 271-276. 
Irons, J.R. \& Masek, J.G. (2006) Requirements for a Landsat Data Continuity Mission, Photogrammetric Engineering and Remote Sensing, 72, pp. 1102-1108.

Irons, J.R., Dwyer, J.L. \& Barsi, J.A. (2012) The next Landsat satellite: The Landsat Data Continuity Mission, Remote Sensing of Environment, 122, pp. 11-21.

JBA (2009) Hydrodynamic and Sediment Transport Modelling Study of the South Ford. Commissioned report for Comhairle nan Eilan Siar, South Ford Hydrodynamics Study, June 2009, 56 pp.

Kachouie, N.N., Huybers, P. \& Schwartzman, A. (2013) Localization of mountain glacier termini in Landsat multi-spectral images, Pattern Recognition Letters, 34, 94-106. DOI: 10.1016/j.patrec.2012.07.003

Klemas, V. (2011) Remote sensing techniques for studying coastal ecosystems: an overview, Journal of Coastal Research, 27, pp. 2-17.

Liu, Y., Huang, H., Qiu, Z. \& Fan, J. (2013) Detecting coastline change from satellite images based on beach slope estimation in a tidal flat, International Journal of Applied Earth Observation and Geoinformation, 23, pp. 165-176.

Loveland, T.R. \& Dwyer, J.L. (2012) Landsat: Building a strong future, Remote Sensing of Environment, 122, pp. 22-29.

Lozano, I., Devoy, R.J.N., May, W. \& Andersen, U. (2004) Storminess and vulnerability along the Atlantic coastlines of Europe: analysis of storm records and of a greenhouse gases induced climate scenario, Marine Geology, 210, 205-225.

Lyons, M.B., Phinn, S.R. \& Roelfsema, C.M. (2012) Long term land cover and seagrass mapping using Landsat and object-based image analysis from 1972 to 2010 in the coastal environment of South East Queensland, Australia. ISPRS Journal of Photogrammetry and Remote Sensing, 71, pp. 34-46.

Maiti, S. \& Bhattacharya, A.K. (2011) A three-unit-based approach in coastal change studies using Landsat images, International Journal of Remote Sensing, 32, pp. 209-229.

Mason, D.C. \& Davenport, I.J. (1996) Accurate and Efficient Determination of the Shoreline in ERS-1 SAR Images, IEEE Transactions on Geosciences and Remote Sensing, 34(5), pp. 1243-1253

McFeeters, S.K. (1996) The use of normalized difference water index (NDWI) in the delineation of open water features, International Journal of Remote Sensing, 17, pp. 1425-1432. 
Morton, R.A., Leach, M.P., Paine, J.G. \& Cardoza, M.A. (1993) Monitoring beach changes using GPS surveying techniques, Journal of Coastal Research, 9, pp. 702-720.

Muslim, A.M., Foody, G.M. \& Atkinson, P.M. (2007) Mapping from Coarse-Spatial Resolution Remote Sensing Imagery of Seberang Takir, Malaysia, Journal of Coastal Research, 23, pp. 13991408.

Nielsen, A.A. (2007) The Regularized Iteratively Reweighted MAD Method for Change Detection in Multi- and Hyperspectral Data, IEEE Transactions on Image Processing, 16, pp. 463-478.

Östlund, C., Flink, P., Strömbeck, N., Pierson, D. \& Lindell, T. (2001) Mapping of the water quality of Lake Erken, Sweden, from Imaging Spectrometry and Landsat Thematic Mapper, Science of the Total Environment, 268, pp. 139-154.

Pahlevan, N. \& Schott, J.R. (2012) Characterizing the relative calibration of Landsat-7 (ETM+) visible bands with Terra (MODIS) over clear waters: The implications for monitoring water resources. Remote Sensing of Environment, 125, pp. 167-180.

Pakeman, R.J., Huband, S., Kriel, A. \& Lewis, R. (2011) Changes in the management of Scottish machair communities and associated habitats from the 1970s to the present, Scottish Geographical Journal, 127, pp. 267-287.

Pardo-Pascual, J.E., Almonacid-Caballer, J., Ruiz, L.A. \& Palomar-Vázquez, J. (2012) Automatic extraction of shorelines from Landsat TM and ETM+ multi-temporal images with subpixel precision, Remote Sensing of Environment, 123, pp. 1-11.

Rahman, A.F., Dragoni, D. \& El-Masri, B. (2011) Response of the Sundarbans coastline to sea level rise and decreased sediment flow: a remote sensing assessment, Remote Sensing of Environment, 115, pp. 3121-3128.

Rennie, A.F. (2006) The role of sediment supply and sea-level changes on a submerging coast, past changes and future management implications. PhD thesis, University of Glasgow, 266 pp.

Ritchie, W. (1968) The coastal geomorphology of North Uist. O’Dell Memorial Monograph n.1 20 pp. University of Aberdeen.

Ritchie, W. (1971) The beaches of Barra and Uists. Countryside Commission for Scotland and republished as Commissioned report N 047 by Scottish Natural Heritage, 98 pp.

Ritchie, W. (1972) The machair of South Uist, Scottish Geographical Magazine, 83, pp. 161-173. 
Ritchie, W. (1979) Machair development and chronology in the Uists and adjacent islands. Proceedings of the Royal Society of Edinburgh. Section B. Biological Sciences, 77, pp.107-122. doi:10.1017/S0269727000012677.

Rowan, J.S., Dawson, S. \& McIlvenney, J. (2010) Sediment core sampling, analysis and dating, South

Ford, Outer Hebrides. Commissioned report Comhairle Nan Eilean Siar (Local Authority for the Western Isles) PE No. TSE/SA/865/68-PE/01

Ryu J-H., Won, J-S. \& Min, K.D. (2002) Waterline extraction from Landsat TM data in a tidal flat A case study in Gomso Bay, Korea, Remote Sensing of Environment, 83, pp. 442-456.

Sallenger, A.H., Krabill, W.B., Swift, R.N., Brock, J., List, J., Hansen, M., Holman, R.A., Manizade, S., Sontag, J., Meredith, A., Morgan, K., Ynkel, J.K., Frederick, E.B. \& Stockdon, H. (2003) Evaluation of airborne topographic lidar for quantifying beach changes, Journal of Coastal Research, 19, pp. 125-133.

Sass, G.Z., Creed, I.F., Bayley, S.E. \& Devito, K.J. (2007) Understanding variation in trophic status of lakes on the Boreal Plain: A 20 year retrospective using Landsat TM imagery, Remote Sensing of Environment, 109, pp. 127-141.

Shalaby, A. \& Tateishi, R. (2007) Remote sensing and GIS for mapping and monitoring land cover and land-use changes in the Northwestern coastal zone of Egypt, Applied Geography, 27, pp. 28-41.

Stockdon, H.F., Sallenger, A.H., List, J.H. \& Holman, R.A. (2002) Estimation of shoreline position and change using airborne topographic lidar data, Journal of Coastal Research, 18, pp. 502-513.

Stoney, W. E. (Noblis Inc.). 2008. ASPRS Guide to Land Imaging Satellites, 15 pp.

Taylor, A. \& O'Donoghue, T. (2009) Morphological change of nourished beach fronted by nearshore structures. In: Allsop, N.W.H. (ed.) Coasts, marine structures and breakwaters 2009: Adapting to Change. Thomas Telford Ltd., London, Vol 2, pp. 176-187.

Thieler, E.R., Himmelstoss, E.A., Zichichi, J.L. \& Ayhan, E. (2009) Digital Shoreline Analysis System (DSAS) version 4.0-An ArcGIS extension for calculating shoreline change: U.S. Geological Survey Open-File Report 2008-1278. * current version 4.3

Thom, B.G. \& Cowell, P.J. (2005) Coastal changes, gradual. In Schwartz M.L. (ed.), Encyclopedia of Coastal Sciences, The Netherlands: Springer, pp. 253-255. 
Vanderstraete, T., Goossens, R. \& Ghabour, T.K. (2006) The use of multi-temporal Landsat images for the change detection of the coastal zone near Hurghada, Egypt, International Journal of Remote Sensing, 27, pp. 3645-3655.

Wang, J. \& Allen, T.R. (2008) Estuarine shoreline change detection using Japanese ALOS PALSAR HH and JERS-1 L-HH SAR data in the Albemarle-Pamlico Sounds, North Carolina, USA, International Journal of Remote Sensing, 29(15), pp. 4429-4442.

Weisse, R., von Storch, H., Niemeyer, H.D. \& Knaack, H. (2012) Changing North Sea storm surge climate: an increasing hazard?, Ocean and Coastal Management, 68, pp. 58-68.

Woodcock, C.E., Allen, R., Anderson, M., Belward, A., Bindschadler, R., Cohen, W.B., Gao, F., Goward, S.N., Helder, D., Helmer, E., Nemani, R., Oreopoulos, L., Schott, J., Thenkabail, P.S., Vermote, E.F., Vogelmann, J., Wulder, M.A. \& Wynne, R. (2008) Free access to Landsat imagery, Science, 320, p. 1011.

Wulder, M.A., White, J.C., Goward, S.N., Masek, J.G., Irons, J.R., Herold, M., Cohen, W.B., Loveland, T.R. \& Woodcock, C.E. (2008) Landsat continuity: Issues and opportunities for land cover monitoring, Remote Sensing of Environment, 112, pp. 955-969.

Wulder, M.A., White, J.C., Masek, J.G., Dwyer, J. \& Roy, D.P. (2011) Continuity of Landsat measures: Short term considerations, Remote Sensing of Environment, 115, 747-751.

Wulder, M.A., Masek, J.G., Cohen, W.B., Loveland, T.R. \& Woodcock, C.E. (2012) Opening the archive: How free data has enabled the science and monitoring promise of Landsat, Remote Sensing of Environment, 122, pp. 2-10.

$\mathrm{Xu}, \mathrm{H}$. (2006) Modification of normalized difference water index (NDWI) to enhance open water features in remotely sensed imagery, International Journal of Remote Sensing, 27, pp. 3025-3033.

Zhang, K., Whitman, D., Leatherman, S. \& Robertson, W. (2005). Quantification of Beach Changes Caused by Hurricane Floyd along Florida's Atlantic Coast Using Airborne Laser Surveys, Journal of Coastal Research, 211, pp. 123-134.

Zhu, Z. \& Woodcock, C.E. (2012) Object-based cloud and cloud shadow detection in Landsat imagery, Remote Sensing of Environment, 118, pp. 83-94. 